\title{
The Apoptotic, Angiogenic and Cell Proliferation Genes CD63, S100A6 e GNB2L1 are Altered in Patients with Endometriosis
}

\section{Os genes apoptóticos, angiogênicos e de proliferação celular CD63, S100A6 e GNB2L1 estão alterados em pacientes com endometriose}

\author{
Valéria Aguiar Gomes ${ }^{1}$ Camila de Moraes Bonocher ${ }^{1}$ Júlio César Rosa-e-Silva ${ }^{1}$ \\ Cláudia Cristina Paro de $\mathrm{Paz}^{2}$ Rui Alberto Ferriani ${ }^{1}$ Juliana Meola ${ }^{1}$ \\ ${ }^{1}$ Department of Gynecology and Obstetrics, School of Medicine of \\ Ribeirao Preto, Universidade de São Paulo, Ribeirão Preto, SP, Brazil \\ 2 Department of Genetics, School of Medicine of Ribeirao Preto, \\ Universidade de São Paulo, Ribeirão Preto, SP, Brazil \\ Address for correspondence Juliana Meola, PhD, Departamento de \\ Ginecologia e Obstetrícia, Escola de Medicina de Ribeirão Preto, \\ Universidade de São Paulo, Av. Bandeirantes, 3900, HC/FMRP, \\ 14049900, Monte Alegre, Ribeirao Preto, SP, Brazil \\ (e-mail: jumeola@yahoo.com.br).
}

Rev Bras Ginecol Obstet 2018;40:606-613.

\begin{abstract}
Keywords

- endometriosis

- gene expression

- molecular genetics

- pathophysiology

- real-time PCR
\end{abstract}

Resumo
Objective The aim of the present study was to analyze the expression of the $C D 63$, S100A6, and GNB2L1genes, which participate in mechanisms related to the complex pathophysiology of endometriosis.

Methods A case-control study was conducted with 40 women who were diagnosed with endometriosis, and 15 fertile and healthy women. Paired samples of eutopic endometrium and endometriotic lesions (peritoneal and ovarian endometriotic implants) were obtained from the women with endometriosis in the proliferative $(n=20)$ or secretory phases $(n=20)$ of the menstrual cycle. As controls, paired endometrial biopsy samples were collected from the healthy women in the proliferative $(n=15)$ and secretory $(n=15)$ phases of the same menstrual cycle. We analyzed the expression levels of the $C D 63, S 100 A 6$, and GNB2L1 genes by real-time polymerase chain reaction.

Results An increase in CD63, S100A6, and GNB2L1 gene transcript levels was observed in the ectopic implants compared with the eutopic endometrium of the women with and without endometriosis, regardless of the phase of the menstrual cycle.

Conclusion These findings suggest that the CD63, S100A6, and GNB2L1 genes may be involved in the pathogenesis of endometriosis, since they participate in mechanisms such as inhibition of apoptosis, angiogenesis and cell proliferation, which lead to the loss of cell homeostasis in the ectopic endometrium, thus contributing to the implantation and survival of the tissue in the extrauterine environment.

Objetivo O objetivo do presente estudo foi analisar a expressão dos genes $C D 63$, S100A6 e GNB2L1, que participam em mecanismos relacionados à complexa fisiopatologia da endometriose. received

February 3, 2018

accepted

June 21, 2018
DOI https://doi.org/

10.1055/s-0038-1673364. ISSN 0100-7203.
Copyright (e 2018 by Thieme Revinter

Publicações Ltda, Rio de Janeiro, Brazil
License terms

(c) (1) 


\section{Palavras-chave}

- endometriose

- expressão gênica

- genética molecular

- fisiopatologia

- PCR em tempo real
Métodos Um estudo caso-controle foi realizado com 40 mulheres diagnosticadas com endometriose e 15 mulheres férteis e saudáveis. Amostras pareadas de endométrio eutópico e de lesões endometrióticas (implantes endometrióticos peritoneais e ovarianos) foram obtidas de mulheres com endometriose nas fases proliferativa ( $n=20)$ ou secretora $(n=20)$ do ciclo menstrual. Como controle, amostras pareadas de biópsia endometrial foram coletadas de mulheres saudáveis nas fases proliferativa ( $n=15)$ e secretora $(n=15)$ no mesmo ciclo menstrual. Foram analisados os níveis de expressão dos genes CD63, S100A6 e GNB2L1 por reação em cadeia da polimerase em tempo real.

Resultados Foi observado um aumento nos níveis de transcritos dos genes $C D 63$, S100A6 e GNB2L1 em implantes ectópicos quando comparado ao endométrio eutópico de mulheres com e sem endometriose, independente da fase do ciclo menstrual.

Conclusão Estes achados sugerem que os genes CD63, S100A6 e GNB2L1 podem estar envolvidos na patogênese da endometriose, pois participam de mecanismos como inibição de apoptose, angiogênese e proliferação celular, os quais levam à perda da homeostase celular no endométrio ectópico e, portanto, contribuem para o implante e a sobrevivência do tecido no ambiente extrauterino.

\section{Introduction}

Endometriosis is a benign gynecological disease that affects at least $10 \%$ of women of reproductive age. ${ }^{1}$ It is defined by the growth of endometrial tissue outside the uterine cavity, which is known as ectopic tissue. Although endometriosis is considered a benign disorder, there are some similarities with cancer; both share invasive potential for the implantation and maintenance of ectopic tissue. Altered immune response, adhesion, invasion, cell proliferation, inhibition of apoptosis, angiogenesis, local estrogen production, and response to injury are important events in the pathogenesis of endometriosis. ${ }^{2}$

Recent studies have demonstrated the molecular differences between the eutopic and the ectopic endometrium, suggesting that distinct patterns of gene expression are involved in the development of endometriosis. ${ }^{3-10}$ The alterations in the expression of certain key genes at specific moments can determine normal and abnormal physiological processes and dysregulate the relevant metabolic pathways influencing the formation of lesions. Therefore, genetic studies are necessary to better understand and define the molecular etiology of this disease.

Previous studies have shown the dysregulation of some genes in endometriosis. These genes are also involved in several pathways, such as the inhibition of apoptosis, cell survival, angiogenesis, and cell proliferation, which suggests their participation in the pathophysiology of endometriosis. ${ }^{3,4}$ In addition, our previous study demonstrated the dysregulation of the CD63, GNB2L, and S100A6 genes in endometriosis. Their involvement in the aforementioned processes and the correlation with cancer suggests that the expression of these genes possibly leads to the establishment and survival of endometriotic implants. ${ }^{3,4}$ Therefore, the evaluation of these genes can clarify some of the mechanisms that underlie the complex pathophysiology of endometriosis.
The purpose of the present study was to compare the expression levels of the CD63, GNB2L1, and S100A6 genes in the endometrial tissue from women without endometriosis, in the eutopic and the ectopic endometrium (pelvic and ovarian endometriotic implants), in the proliferative and secretory phases of the menstrual cycle from the patients with endometriosis.

\section{Methods}

\section{Ethics, Setting, and Duration}

A case-control study was conducted on patients with and without endometriosis in the proliferative and secretory phases of the menstrual cycle. The present study was performed from 2010 to 2012 at the Sector of Human Reproduction from the Department of Gynecology and Obstetrics of Faculdade de Medicina de Ribeirão Preto da Universidade de São Paulo (FMRP-USP), in the state of São Paulo, Brazil. The present study was approved by the Institutional Review Board of the FMRP-USP, protocol HCRP $\mathrm{n}^{\circ} 11736 / 2004$, and is linked to a bank of endometriosis tissues, which is also approved, protocol HCRP $\mathrm{n}^{\circ}$ 9699/2006. All subjects (those with endometriosis and the controls) signed a written informed consent to participate in the study. The present work was performed in accordance with the ethical standards of the Declaration of Helsinki.

\section{Participants and Eligibility Criteria}

The women were included if they were 18 to 40 years old, had a body mass index $(\mathrm{BMI})<30 \mathrm{~kg} / \mathrm{m}^{2}$, were not menopausal, had not been taking any hormonal therapy for at least 3 months before sample collection, had no reproductive disorder or tumor, and had a regular menstrual cycle. Other exclusion criteria included smoking, alcoholism, recreational drug use, 
any systemic disease (systemic arterial hypertension, diabetes mellitus, immune system diseases, or thyroid diseases).

The patients of the endometriosis group were diagnosed through laparoscopy and histopathological analyses. An experienced surgeon performed the laparoscopy, and the stage of endometriosis was determined according to the classification of the American Society for Reproductive Medicine (1997). ${ }^{11}$

The control group consisted of women of reproductive age (18 to 40 years old), who were submitted to laparoscopy for tubal ligation. These women did not have endometriosis, fibrosis, pelvic adhesion, or infertility.

\section{Sample Collection and Processing}

\section{Tissue Samples}

The paired tissue samples of the eutopic endometrium and of the endometriotic lesions (peritoneal or ovarian lesions) were collected from 40 women with endometriosis during laparoscopy, and the eutopic endometrial samples were collected using a Euro-Med Novak Endometrial Curette (CooperSurgical, Inc., Trumbull, CT, USA). Only one sample was collected per patient. In the control group, two paired biopsy tissue samples were collected from 15 healthy women according to the phase of the menstrual cycle. The phases of the cycle were determined by histological dating. The samples were stored frozen at $-80^{\circ} \mathrm{C}$ for later analysis after treatment with RNAlater Stabilization Solution (Thermo Fischer Scientific, Waltham, MA, USA).

\section{Total RNA Extraction}

The samples were washed with phosphate-buffered saline (PBS) solution ( $1 \mathrm{x})\left(8.50 \mathrm{~g} / \mathrm{L} \mathrm{NaCl}, 1.11 \mathrm{~g} / \mathrm{L} \mathrm{Na}_{2} \mathrm{HPO}_{4}\right.$, and 2.81 $\mathrm{g} / \mathrm{L} \mathrm{Na}_{2} \mathrm{HPO}_{4}, 12 \mathrm{H}_{2} \mathrm{O}, 0.20 \mathrm{~g} / \mathrm{L}$, and $\mathrm{KH}_{2} \mathrm{PO}_{4}, \mathrm{pH}$ 7.0) to remove the RNAlater solution from the tissues. Next, total RNA (50 mg tissue) was extracted using the TRIzol reagent (Thermo Fischer Scientific, Waltham, MA, USA) according to the manufacturer's instructions. After the treatment of the samples with DNase I (Thermo Fischer Scientific, Waltham, MA, USA), RNA integrity was confirmed by the presence of the ribosomal bands (28S and $18 \mathrm{~S}$ ) after analysis by $1 \%$ agarose gel electrophoresis. Total RNA concentrations were determined using a NanoDrop 2000c spectrophotometer (Thermo Fischer Scientific, Waltham, MA, USA) at $260 \mathrm{~nm}$. The RNA was stored at $-80^{\circ} \mathrm{C}$ until further processing.

\section{Relative Quantification by Real-time Polymerase Chain Reaction}

An aliquot $(1 \mu \mathrm{g})$ of total RNA from each sample was reversetranscribed using random primers from the High Capacity cDNA Archive kit (Thermo Fischer Scientific, Waltham, MA, USA) according to the manufacturer's instructions. The reaction was performed in a Piko Thermal Cycler (Thermo Fischer Scientific, Waltham, MA, USA) for 10 minutes at $25^{\circ} \mathrm{C} ; 2$ hours at $37^{\circ} \mathrm{C} ; 5$ minutes at $85^{\circ} \mathrm{C}$, and 5 minutes at $4^{\circ} \mathrm{C}$.

The relative quantification ( $R Q$ ) of the expression of the selected genes in the collected samples was performed using an ABI PRISM 7500 FAST equipment (Applied Biosystems, Foster
City, CA, USA). The reactions were performed using the TaqMan Gene Expression Assay system, being the TaqMan probe with FAM dye label on the $5^{\prime}$ end and minor groove binder (MGB) and nonfluorescent quencher (NFQ) on the $3^{\prime}$ end. This information is an explanation of which TaqMan Gene Expressed Assay was used. (Applied Biosystems, Foster City, CA, USA). The assay IDs of the probes used were CD63 (Hs00156390_m1), GNB2L1(Hs00272002_m1),S100A6(Hs00170953_m1), GAPDH (Hs99999905_m1), and АCTB (Hs99999903_m1).

Real-time polymerase chain reaction (It's qRT-PCR. RealTime Quantitative Reverse Transcription PCR. RT-PCR is Reverse transcription-polymerase chain reaction) was performed in triplicate for each sample using a reaction mixture with a final volume of $20 \mu \mathrm{L}$ consisting of the following: $10 \mu \mathrm{L}$ TaqMan Universal PCR Master Mix (2x) (Applied Biosystems, Foster City, CA, USA), $1 \mu \mathrm{L}$ TaqMan Gene Expression Assay Mix (20x) (Applied Biosystems, Foster City, CA, USA), and $9 \mu \mathrm{L}$ cDNA diluted 1:50. The reaction conditions were $50^{\circ} \mathrm{C}$ for 2 minutes, $95^{\circ} \mathrm{C}$ for 10 minutes, 40 cycles of $95^{\circ} \mathrm{C}$ for 15 seconds and $60^{\circ} \mathrm{C}$ for 1 minute.

A cDNA pool of the endometrial samples $(n=30)$ obtained from the control group was used as a reference sample (calibrator). The reference genes GAPDH and ACTB were used for normalizing the reactions. Relative quantification of the analyzed genes was calculated for each sample (control group $=30$; and endometriosis group $=40$ ) by the $2^{-\Delta \Delta \mathrm{CT}}$ method. $^{12}$

\section{Statistical Methods}

Statistical analyses were performed with the aid of the SAS 2003 software (SAS Institute Inc., Cary, NC, USA). The RQ values of the genes were log-transformed $\left(\log _{10}\left[2^{-\triangle \Delta C T} \mathrm{t}+10\right]\right)$. Logarithmic transformation was necessary, since one of the assumptions (linearity) of the linear model analysis was not satisfied.

The analysis of variance (ANOVA) was performed by including the effects of phases of the menstrual cycle (proliferative and secretory), the type of tissue (peritoneal lesion, endometrioma, eutopic endometrium of patients with and without endometriosis) as well as the interactions among them in the statistical model.

We used the $t$-test for paired samples (eutopic endometrium versus ectopic lesions), and the Welch ANOVA test for unpaired samples (control endometrium versus eutopic endometrium of patients with endometriosis, control endometrium versus lesions of patients with endometriosis, and peritoneal lesions versus ovarian lesions).

Data, which are $\log _{10}\left(2^{-\Delta \Delta C T}+10\right)$-transformed, are illustrated in - Fig. 1 with mean and standard deviation (SD). The analyses were satisfactory, with a test power (1- $\beta$ ) of at least $80 \%$, and the results were considered statistically significant when $p<0.05$.

\section{Results}

There was no significant difference between the endometriosis and control groups regarding mean age and standard deviation $(33.87 \pm 2.69$ and $33.5 \pm 4.37$ years old, 


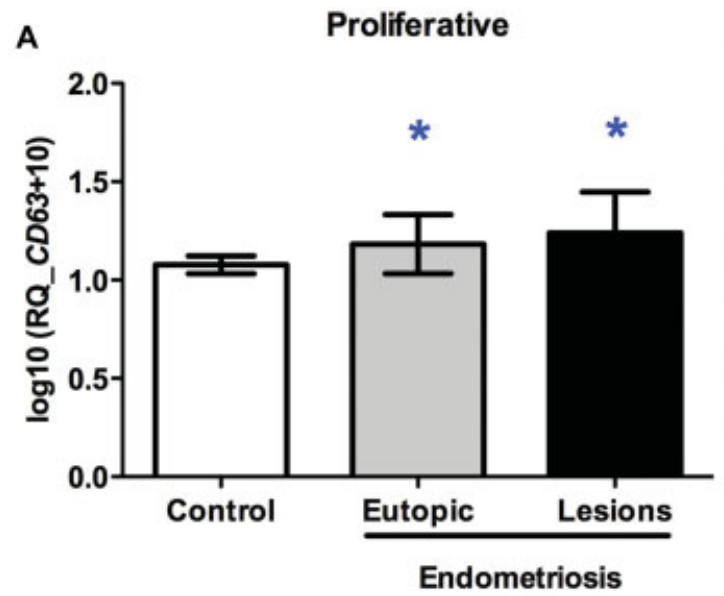

B Secretory
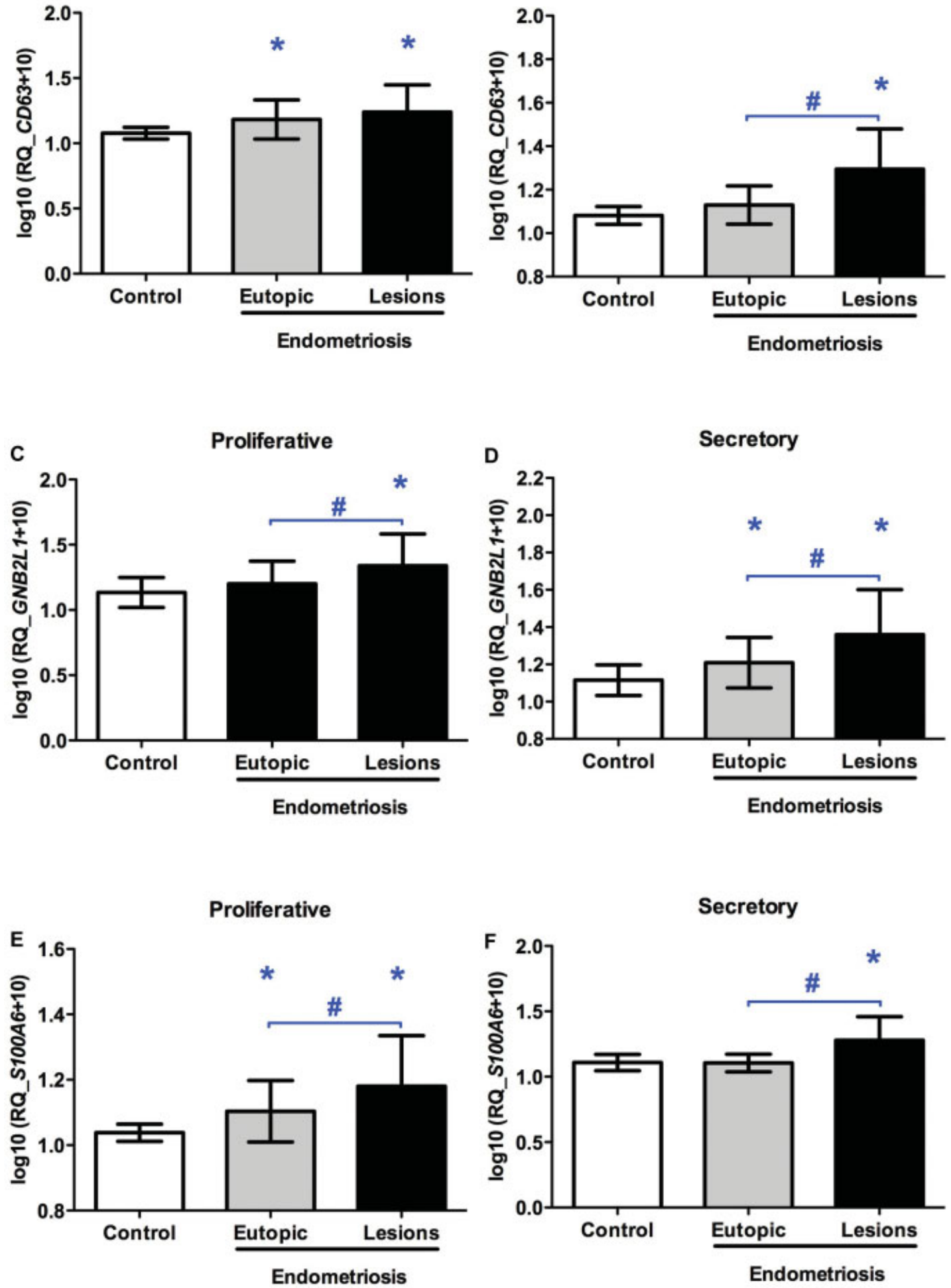

Fig. 1 Relative expression of the CD63, GNB2L1 and S100A6 genes in human endometrial tissue throughout the menstrual cycle. (A) Relative expression of the $C D 63$ gene in the proliferative phase, (B) relative expression of the $C D 63$ gene in the secretory phase, (C) relative expression of the GNB2L1 gene in the proliferative phase, (D) relative expression of the GNB2L1 gene in the secretory phase, (E) relative expression of the $S 100 \mathrm{~A} 6$ gene in the proliferative phase and (F) relative expression of the S100A6 gene in the secretory phase. Control = endometrium of women without endometriosis; Eutopic = endometrium of women with endometriosis; Lesions = endometriotic lesions (peritoneal and ovarian lesions). ${ }^{*} p<0.05$ versus control group (unpaired analyses). $\# p<0.05$ versus eutopic group (paired analyses). Data are shown as mean \pm standard deviation. 
respectively). The control group consisted of 15 women of reproductive age. Fifteen biopsy samples were obtained during the proliferative phase, and 15 during the secretory phase of the menstrual cycle. The endometriosis group consisted of 40 women, and of these patients, 21 were attended to due to infertility, and 19 due to pelvic pain at the outpatient clinics of marital infertility, and pelvic pain and endoscopy of the university hospital of the FMRP-USP. The number of peritoneal lesions studied in the patients classified as stage I ( $n=6$; in the secretory phase), stage II ( $n=11 ; 7$ in the proliferative phase and 4 in the secretory phase), stage III ( $n=2$; in the proliferative phase), and stage IV ( $n=1$; in the proliferative phase) was 20 , and that of the ovarian endometrioma lesions studied in the patients classified as stage III $(n=8 ; 4$ in the proliferative phase and 4 in the secretory phase) and stage IV ( $n=12 ; 6$ in the proliferative phase and 6 in the secretory phase) was 20 .

The results of gene expression in the analyzed tissues are illustrated in - Fig. 1. There was no difference in the expression of target genes between the peritoneal and ovarian lesions (data not shown). Thus, the peritoneal and endometrioma lesions were pooled for the remaining analyses.

Increased expression of the CD63, GNB2L1, and S100A6 genes was found in the endometriotic lesions regardless of the phases of the menstrual cycle that were studied (- Fig. 1). Furthermore, increased expression of the $C D 63$, and of the S100A6 genes (in the proliferative phase), and of the GNB2L1 gene (in the secretory phase) was detected in the eutopic endometrium of the patients of the endometriosis group compared with the control endometrium (-Figs. 1A, E and $\mathbf{D}$; respectively). However, when the proliferative and secretory phases were compared with each other in the endometrial control (CD63 $p=0.52 ;$ GNBL1 $p=0.79$; S100A6 $p=0.052$ ), eutopic endometrium (CD63 $p=0.38$; GNBL1 $p=0.41 ;$ S100A6 $p=0.44)$ and endometriotic lesions $(C D 63 p=0.94 ;$ GNBL1 $p=0.49 ;$ S100A6 $p=0.24)$, no difference was observed.

\section{Discussion}

The present study identified the increased expression of the CD63, GNB2L1, and S100A6 genes in the ectopic lesions of women with endometriosis compared with the endometrium of the control group during both the proliferative and secretory phases of the menstrual cycle. In addition, the expression of these genes had increased in the lesions compared with the eutopic endometrium of the same endometriosis patient during the secretory phase of the menstrual cycle. However, when the eutopic endometrium of the women with endometriosis were compared with the endometrium of the control women, the expression of the CD63 and of the S100A6 genes had increased only in the proliferative phase in the endometrium of the women with endometriosis, and the increased expression of the GNB2L1 gene was observed only in the secretory phase.

These results are in agreement with our previously obtained results, which showed the increased expression of the target genes in endometriotic lesions in a large-scale hybridization study based on subtractive libraries. ${ }^{3}$ However, in the present study, we used RT-PCR to quantify and confirm the dysregulated expression of these genes during the phases of the menstrual cycle. This technique has been defined as the gold standard for transcript quantification due to its high sensitivity and good reproducibility. In addition, possible false-positive results can be revealed when this technique is used for the validation of screening methodologies. ${ }^{13}$ The obtained results confirmed the increased expression of these genes in endometriotic lesions.

One of the possible explanations for the differences observed between the eutopic and the ectopic endometrium of the patients with endometriosis is that endometriosis is a multifactorial disorder, which is influenced by genetic and environmental factors. Studies have shown that different endocrine environments, such as the peritoneal fluid and the intraovarian microenvironment of the lesions, are critical to endometrial implantation, suggesting that the interaction between these different endocrine environments and the ectopic endometrium is important in the pathophysiology of endometriosis. $^{14}$

In the present study, we have detected the increased expression of the $C D 63$ gene in endometrial lesions compared with the eutopic tissue of women with and without endometriosis. The human CD63 gene, which codes for a tetraspanin, has been mapped to the chromosome region $12 q 13$, and was first discovered as a surface antigen that is abundantly expressed in cells in the initial stage of melanoma and on the surface of activated blood platelets. ${ }^{15}$ The $C D 63$ gene interacts directly and indirectly with various molecules, such as integrins, other tetraspanins, cell surface receptors, kinases, protein adaptors, and other proteins, including the L6 antigen, syntenin-1, TIMP1, and MT1-MMP. ${ }^{16-27}$ The CD63 gene was recently identified to bind to the TIMP-1 protein, which is known to be involved in several cellular processes and in tumor development. ${ }^{26}$ The complex of $C D 63$, TIMP- 1 and $\beta 1$ integrin mediates the activation of cell survival pathways through the activation of the focal adhesion kinase (FAK), as well as of the PI3-K and extracellular signal-regulated kinase (ERK) pathways, and to the inhibition of apoptosis. $^{26,28,29}$ Therefore, we hypothesized that the increase in the expression of the $C D 63$ gene may be related to the promotion of the survival of ectopic endometrial cells, thus favoring the development of endometriotic lesions.

Another important gene that was suggested by Meola et $\mathrm{al}^{3}$ and Dentillo et $\mathrm{al}^{4}$ to be involved in the pathophysiology of endometriosis is GNB2L1, which is commonly called RACK1 (receptor for activated C-kinase 1) and is located in the chromosome region $5 q 35$.3. It possesses $7 \mathrm{WD}$ domains (tryptophan-aspartate), which provides RACK1 with the potential to act as an adaptor or scaffold protein in the interactions with various molecules. ${ }^{3,4,30}$ Many cellular functions are attributed to $R A C K 1$, such as cell growth, chemotactic adhesion and migration, which are mediated by the interaction with integrin and Src, as well as the suppression of apoptosis, anti-inflammation and angiogenesis. ${ }^{31-35}$

In our study, the expression of the GNB2L1 gene was considerably higher in endometriotic lesions than in the eutopic endometria of women with and without endometriosis. Studies 
have indicated that the overexpression of this gene positively regulates cell adhesion and migration. ${ }^{36}$ The increased expression of the GNB2L1gene and its interaction with IGF-IR augmented the mobility of transformed MCF-7 cells, showing that this gene promotes the anchorage-independent growth of ovarian tumor cells via the insulin growth factor $1 \mathrm{R}$ (IGF-1R)/ STAT3 pathway, whereas other authors had reported discordant results when analyzing the Src pathway. ${ }^{37-40}$ Moreover, the GNB2L1 gene is also overexpressed during angiogenesis, and in breast and colon tumors, non-small cell lung carcinoma, oral squamous cell carcinoma, and melanoma. ${ }^{31,41-44}$ Thus, the upregulation of the expression of the GNB2L1 gene suggests its participation in processes such as angiogenesis, suppression of apoptosis, and cell proliferation, which are the steps involved in the pathology of endometriosis.

The third gene evaluated was S100A6, whose expression had increased considerably in endometriotic lesions compared with the eutopic endometrium of women with and without endometriosis. The $5100 \mathrm{~A} 6$ gene, whose protein product is also known as calcyclin, has $\mathrm{Ca}^{2+}$-binding sites. ${ }^{45}$ Some of the functions associated with this protein and changes in the expression of this gene include cytoskeleton dynamics, cell cycle, apoptosis, overexpression in cells with proliferative potential, and increased induction of cell proliferation. ${ }^{46-51}$

Liu et $\mathrm{al}^{52}$ showed that the overexpression of the S100A6 gene in endometrial stromal cells promoted the upregulation of $\beta$-catenin expression. The $\beta$-catenin is an essential component of the Wnt/ $\beta$-catenin signaling pathway, which has been demonstrated to be activated in the mid-secretory endometrium of infertile patients with endometriosis. ${ }^{53}$ This pathway is involved in the control of proliferation, migration, and invasion, which are important steps in the pathogenesis of endometriosis. Recently, Zhang et $\mathrm{al}^{54} \mathrm{dem}-$ onstrated that inhibition of the expression of the S100A6 gene significantly reduced the migratory ability of eutopic endometrial stromal cells, induced their apoptosis, and had antiproliferative effect. In addition, both increased protein levels and increased transcript levels of the S100A6 gene have been observed in many types of tumors. ${ }^{54}$

The increased protein levels of the S100A6 gene promote cell apoptosis under oxidative stress. ${ }^{55}$ However, the proapoptotic function of this gene is contradictory, as reduced expression of this gene has been observed during the apoptosis of human breast cancer cells, and the expression of the S100A6 gene has also been demonstrated to inhibit the apoptosis of cardiac myocytes. ${ }^{56,57}$ An increased expression of this gene increases cell adhesion and inhibition of cell invasion, and promotes mobility in a way that is yet to be understood. ${ }^{58,59}$ However, when its expression is insufficient or is negatively regulated, this gene inhibits the proliferation of fibroblasts, osteoblasts, and pancreatic tumor cells. ${ }^{46,60,61}$ Since the S100A6 gene is involved in cell cycle progression, cell differentiation, the interactions with the cytoskeleton, and cell proliferation, it is possible that the changes in the expression of this gene that were observed in the present study could be implicated in the development of endometriosis.

No differences in the levels of expression of the studied genes were observed when the proliferative and secretory phases were compared with each other in the endometrial control, in eutopic endometria and in endometriotic lesions. However, the eutopic endometria of women with endometriosis had an increased expression of the CD63 and S100A6 genes in the proliferative phase, while the increased expression of the GNB2L1 gene was observed in the secretory phase when compared with the control group; these results could be explained by the changes related to the disease. Although some authors relate the changes of gene expression with hormonal fluctuations, there are few studies and there are controversies in the literature regarding the genes studied. Okada et $\mathrm{al}^{62}$ showed that the mRNA levels of the CD63 gene were substantially reduced during the secretory phase of the menstrual cycle compared with the proliferative phase, and that the expression of the mRNAs is negatively regulated by progesterone, thus associating this gene with functions such as proliferation and differentiation of the endometrium (decidualization). In contrast, Brar et $\mathrm{al}^{63}$ found no change in the expression of this gene during decidualization. Tong et $\mathrm{l}^{64}$ studied the expression of the S100A6 gene in the human endometrium throughout the menstrual cycle, and no change was detected.

A limitation of our study was the small sample evaluated due to the restrictive eligibility criteria adopted, limiting the generalization of the study.

\section{Conclusion}

Our results suggest that the altered expression of the $C D 63$, S100A6, and GNB2L1 genes may be involved in the pathophysiology of endometriosis. This is because the CD63, RACK1 and calcyclin proteins participate in the inhibition of apoptosis, angiogenesis and cell proliferation, which can lead to the loss of cell homeostasis in the ectopic endometrium. Future studies are needed to assess the function of the identified genes, and to characterize their roles in the development of the disease. Another aspect that should be addressed is that our study was based on the premise that tissue invasion occurs due to the reflux of viable endometrial cells. Although this idea is still one of the most accepted today, it is only a hypothesis that has not been confirmed.

\section{Conflict of Interests}

None to declare.

\section{Acknowledgments}

We are grateful to all the patients for their participation in the present study and to the multidisciplinary team of the Human Reproduction Division of the Department of Gynecology and Obstetrics at FMRP-USP for the sample collection and technical support.

\section{References}

1 Yang WC, Chen HW, Au HK, et al. Serum and endometrial markers. Best Pract Res Clin Obstet Gynaecol 2004;18(02):305-318 Doi: 10.1016/j.bpobgyn.2004.03.003

2 Nap AW, Groothuis PG, Demir AY, Evers JL, Dunselman GA. Pathogenesis of endometriosis. Best Pract Res Clin Obstet Gynaecol 2004;18(02):233-244 Doi: 10.1016/j.bpobgyn.2004.01.005 
3 Meola J, Rosa e Silva JC, Dentillo DB, et al. Differentially expressed genes in eutopic and ectopic endometrium of women with endometriosis. Fertil Steril 2010;93(06):1750-1773 Doi: 10.1016/j. fertnstert.2008.12.058

4 Dentillo DB, Meola J, Rosa e Silva JC, et al. Deregulation of LOXL1 and HTRA1 gene expression in endometriosis. Reprod Sci 2010;17 (11):1016-1023 Doi: 10.1177/1933719110377662

5 Honda H, Barrueto FF, Gogusev J, Im DD, Morin PJ. Serial analysis of gene expression reveals differential expression between endometriosis and normal endometrium. Possible roles for AXL and SHC1 in the pathogenesis of endometriosis. Reprod Biol Endocrinol 2008;6:59 Doi: 10.1186/1477-7827-6-59

6 Filigheddu N, Gregnanin I, Porporato PE, et al. Differential expression of microRNAs between eutopic and ectopic endometrium in ovarian endometriosis. J Biomed Biotechnol 2010;2010:369549

7 Hu WP, Tay SK, Zhao Y. Endometriosis-specific genes identified by real-time reverse transcription-polymerase chain reaction expression profiling of endometriosis versus autologous uterine endometrium. J Clin Endocrinol Metab 2006;91(01):228-238 Doi: $10.1210 /$ jc.2004-1594

8 Wu Y, Kajdacsy-Balla A, Strawn E, et al. Transcriptional characterizations of differences between eutopic and ectopic endometrium. Endocrinology 2006;147(01):232-246 Doi: 10.1210/en.2005-0426

9 Eyster KM, Klinkova O, Kennedy V, Hansen KA. Whole genome deoxyribonucleic acid microarray analysis of gene expression in ectopic versus eutopic endometrium. Fertil Steril 2007;88(06): 1505-1533 Doi: 10.1016/j.fertnstert.2007.01.056

10 Hull ML, Escareno CR, Godsland JM, et al. Endometrial-peritoneal interactions during endometriotic lesion establishment. Am J Pathol 2008;173(03):700-715 Doi: 10.2353/ajpath.2008.071128

11 Revised American Society for Reproductive Medicine classification of endometriosis: 1996. Fertil Steril 1997;67(05):817-821 Doi: 10.1016/S0015-0282(97)81391-X

12 Livak KJ, Schmittgen TD. Analysis of relative gene expression data using real-time quantitative PCR and the 2(-Delta Delta C(T)) Method. Methods 2001;25(04):402-408 Doi: 10.1006/meth.2001.1262

13 Goodsaid FM, Smith RJ, Rosenblum IY. Quantitative PCR deconstruction of discrepancies between results reported by different hybridization platforms. Environ Health Perspect 2004;112(04): 456-460

14 Fujii EY, Nakayama M, Nakagawa A. Concentrations of receptor for advanced glycation end products, VEGF and CML in plasma, follicular fluid, and peritoneal fluid in women with and without endometriosis. Reprod Sci 2008;15(10):1066-1074 Doi: 10.1177/ 1933719108323445

15 Hotta H, Ross AH, Huebner K, et al. Molecular cloning and characterization of an antigen associated with early stages of melanoma tumor progression. Cancer Res 1988;48(11):2955-2962

16 Berditchevski F, Zutter MM, Hemler ME. Characterization of novel complexes on the cell surface between integrins and proteins with 4 transmembrane domains (TM4 proteins). Mol Biol Cell 1996;7(02):193-207 Doi: 10.1091/mbc.7.2.193

17 Radford KJ, Thorne RF, Hersey P. CD63 associates with transmembrane 4 superfamily members, CD9 and CD81, and with beta 1 integrins in human melanoma. Biochem Biophys Res Commun 1996;222(01):13-18 Doi: 10.1006/bbrc.1996.0690

18 Hammond C, Denzin LK, Pan M, Griffith JM, Geuze HJ, Cresswell P. The tetraspan protein CD82 is a resident of MHC class II compartments where it associates with HLA-DR, -DM, and -DO molecules. J Immunol 1998;161(07):3282-3291

19 Kitani S, Berenstein E, Mergenhagen S, Tempst P, Siraganian RP. A cell surface glycoprotein of rat basophilic leukemia cells close to the high affinity IgE receptor (Fc epsilon RI). Similarity to human melanoma differentiation antigen ME491. J Biol Chem 1991;266 (03):1903-1909

20 Levy S, Shoham T. The tetraspanin web modulates immunesignalling complexes. Nat Rev Immunol 2005;5(02):136-148 Doi: $10.1038 /$ nri1548
21 Yoshida T, Kawano Y, Sato K, et al. A CD63 mutant inhibits T-cell tropic human immunodeficiency virus type 1 entry by disrupting CXCR4 trafficking to the plasma membrane. Traffic 2008;9(04): 540-558 Doi: 10.1111/j.1600-0854.2008.00700.x

22 Skubitz KM, Campbell KD, Iida J, Skubitz AP. CD63 associates with tyrosine kinase activity and CD11/CD18, and transmits an activation signal in neutrophils. J Immunol 1996;157(08):3617-3626

23 Hirst J, Bright NA, Rous B, Robinson MS. Characterization of a fourth adaptor-related protein complex. Mol Biol Cell 1999;10 (08):2787-2802 Doi: 10.1091/mbc.10.8.2787

24 Lekishvili T, Fromm E, Mujoomdar M, Berditchevski F. The tumourassociated antigen L6 (L6-Ag) is recruited to the tetraspaninenriched microdomains: implication for tumour cell motility. J Cell Sci 2008;121(Pt 5):685-694 Doi: 10.1242/jcs.020347

25 Latysheva N, Muratov G, Rajesh S, et al. Syntenin-1 is a new component of tetraspanin-enriched microdomains: mechanisms and consequences of the interaction of syntenin- 1 with CD63. Mol Cell Biol 2006;26(20):7707-7718 Doi: 10.1128/MCB.00849-06

26 Jung KK, Liu XW, Chirco R, Fridman R, Kim HR. Identification of CD63 as a tissue inhibitor of metalloproteinase- 1 interacting cell surface protein. EMBO J 2006;25(17):3934-3942 Doi: 10.1038/sj. emboj.7601281

27 Schröder HM, Hoffmann SC, Hecker M, Korff T, Ludwig T. The tetraspanin network modulates MT1-MMP cell surface trafficking. Int J Biochem Cell Biol 2013;45(06):1133-1144 Doi: 10.1016/ j.biocel.2013.02.020

28 Toricelli M, Melo FH, Peres GB, Silva DC, Jasiulionis MG. Timp1 interacts with beta- 1 integrin and CD63 along melanoma genesis and confers anoikis resistance by activating PI3-K signaling pathway independently of Akt phosphorylation. Mol Cancer 2013; 12:22 Doi: 10.1186/1476-4598-12-22

29 Jung YS, Liu XW, Chirco R, Warner RB, Fridman R, Kim HR. TIMP-1 induces an EMT-like phenotypic conversion in MDCK cells independent of its MMP-inhibitory domain. PLoS One 2012;7(06): e38773 Doi: 10.1371/journal.pone.0038773

30 Ron D, Chen CH, Caldwell J, Jamieson L, Orr E, Mochly-Rosen D. Cloning of an intracellular receptor for protein kinase C: a homolog of the beta subunit of $G$ proteins. Proc Natl Acad Sci U S A 1994;91(03):839-843 Doi: 10.1073/pnas.91.3.839

31 Berns H, Humar R, Hengerer B, Kiefer FN, Battegay EJ. RACK1 is upregulated in angiogenesis and human carcinomas. FASEB J 2000; 14(15):2549-2558 Doi: 10.1096/fj.99-1038com

32 Chang BY, Harte RA, Cartwright CA. RACK1: a novel substrate for the Src protein-tyrosine kinase. Oncogene 2002;21(50):7619-7629 Doi: $10.1038 /$ sj.onc.1206002

33 Cox EA, Bennin D, Doan AT, O’Toole T, Huttenlocher A. RACK1 regulates integrin-mediated adhesion, protrusion, and chemotactic cell migration via its Src-binding site. Mol Biol Cell 2003;14 (02):658-669 Doi: 10.1091/mbc.e02-03-0142

34 Mourtada-Maarabouni M, Kirkham L, Farzaneh F, Williams GT Functional expression cloning reveals a central role for the receptor for activated protein kinase C 1 (RACK1) in T cell apoptosis. J Leukoc Biol 2005;78(02):503-514 Doi: 10.1189/ jlb.0205070

35 Viviani B, Corsini E, Binaglia M, Lucchi L, Galli CL, Marinovich M. The anti-inflammatory activity of estrogen in glial cells is regulated by the PKC-anchoring protein RACK-1. J Neurochem 2002;83 (05):1180-1187

36 Doan AT, Huttenlocher A. RACK1 regulates Src activity and modulates paxillin dynamics during cell migration. Exp Cell Res 2007;313(12):2667-2679 Doi: 10.1016/j.yexcr.2007.05.013

37 Chang BY, Conroy KB, Machleder EM, Cartwright CA. RACK1, a receptor for activated $C$ kinase and a homolog of the beta subunit of $\mathrm{G}$ proteins, inhibits activity of src tyrosine kinases and growth of NIH 3T3 cells. Mol Cell Biol 1998;18(06):3245-3256 Doi: 10.1128/MCB.18.6.3245

38 Mamidipudi V, Chang BY, Harte RA, Lee KC, Cartwright CA. RACK1 inhibits the serum- and anchorage-independent growth of $\mathrm{v}$-Src 
transformed cells. FEBS Lett 2004;567(2-3):321-326 Doi: 10.1016/j.febslet.2004.03.125

39 Kiely PA, O'Gorman D, Luong K, Ron D, O'Connor R. Insulin-like growth factor I controls a mutually exclusive association of RACK1 with protein phosphatase $2 \mathrm{~A}$ and beta1 integrin to promote cell migration. Mol Cell Biol 2006;26(11):4041-4051 Doi: 10.1128/ MCB.01868-05

40 Zhang W, Cheng GZ, Gong J, et al. RACK1 and CIS mediate the degradation of BimEL in cancer cells. J Biol Chem 2008;283(24): 16416-16426 Doi: 10.1074/jbc.M802360200

41 Saito A, Fujii G, Sato Y, et al. Detection of genes expressed in primary colon cancers by in situ hybridisation: overexpression of RACK 1. Mol Pathol 2002;55(01):34-39

42 Egidy G, Julé S, Bossé P, et al. Transcription analysis in the MeLiM swine model identifies RACK1 as a potential marker of malignancy for human melanocytic proliferation. Mol Cancer 2008; 7:34 Doi: 10.1186/1476-4598-7-34

43 Shipitsin M, Campbell LL, Argani P, et al. Molecular definition of breast tumor heterogeneity. Cancer Cell 2007;11(03):259-273 Doi: $10.1016 /$ j.ccr.2007.01.013

44 Wang Z, Zhang B, Jiang L, et al. RACK1, an excellent predictor for poor clinical outcome in oral squamous carcinoma, similar to Ki67. Eur J Cancer 2009;45(03):490-496 Doi: 10.1016/j. ejca.2008.11.012

45 Sastry M, Ketchem RR, Crescenzi O, et al. The three-dimensional structure of $\mathrm{Ca}(2+)$-bound calcyclin: implications for $\mathrm{Ca}(2+)$ signal transduction by S100 proteins. Structure 1998;6(02): 223-231 Doi: 10.1016/S0969-2126(98)00023-9

46 Hwang R, Lee EJ, Kim MH, et al. Calcyclin, a Ca2+ ion-binding protein, contributes to the anabolic effects of simvastatin on bone. J Biol Chem 2004;279(20):21239-21247 10.1074/jbc.M312771200

47 Kuźnicki J, Filipek A. Purification and properties of a novel Ca2+binding protein $(10.5 \mathrm{kDa})$ from Ehrlich-ascites-tumour cells. Biochem J 1987;247(03):663-667 Doi: 10.1042/bj2470663

48 Filipek A, Zasada A, Wojda U, Makuch R, Dabrowska R. Characterization of chicken gizzard calcyclin and examination of its interaction with caldesmon. Comp Biochem Physiol B Biochem Mol Biol 1996;113(04):745-752 Doi: 10.1016/0305-0491(95) 02095-0

49 Golitsina NL, Kordowska J, Wang CL, Lehrer SS. Ca2+-dependent binding of calcyclin to muscle tropomyosin. Biochem Biophys Res Commun 1996;220(02):360-365 Doi: 10.1006/bbrc. 1996.0410

50 Leśniak W, Słomnicki ŁP, Filipek A. S100A6 - new facts and features. Biochem Biophys Res Commun 2009;390(04):1087-1092 Doi: 10.1016/j.bbrc.2009.10.150

51 Hirschhorn RR, Aller P, Yuan ZA, Gibson CW, Baserga R. Cell-cyclespecific cDNAs from mammalian cells temperature sensitive for growth. Proc Natl Acad Sci U S A 1984;81(19):6004-6008
52 Liu Z, Zhang X, Chen M, Cao Q, Huang D. Effect of S100A6 overexpression on $\beta$-catenin in endometriosis. J Obstet Gynaecol Res 2015;41(09):1457-1462 Doi: 10.1111/jog.12729

53 Matsuzaki S, Darcha C, Maleysson E, Canis M, Mage G. Impaired down-regulation of E-cadherin and beta-catenin protein expression in endometrial epithelial cells in the mid-secretory endometrium of infertile patients with endometriosis. J Clin Endocrinol Metab 2010;95(07):3437-3445 Doi: 10.1210/jc.2009-2713

54 Zhang X, Liu Z, Chen M, Cao Q, Huang D. Effects of S100A6 gene silencing on the biological features of eutopic endometrial stromal cells and $\beta$-catenin expression. Mol Med Rep 2017;15(03): 1279-1285 Doi: 10.3892/mmr.2017.6105

55 Słomnicki ŁP, Nawrot B, Leśniak W. S100A6 binds p53 and affects its activity. Int J Biochem Cell Biol 2009;41(04):784-790 Doi: 10.1016/j.biocel.2008.08.007

56 Tsoporis JN, Izhar S, Parker TG. Expression of S100A6 in cardiac myocytes limits apoptosis induced by tumor necrosis factoralpha. J Biol Chem 2008;283(44):30174-30183 Doi: 10.1074/ jbc.M805318200

57 Leong S, Christopherson RI, Baxter RC. Profiling of apoptotic changes in human breast cancer cells using SELDI-TOF mass spectrometry. Cell Physiol Biochem 2007;20(05):579-590 Doi: 10.1159/000107541

58 Nedjadi T, Kitteringham N, Campbell F, et al. S100A6 binds to annexin 2 in pancreatic cancer cells and promotes pancreatic cancer cell motility. Br J Cancer 2009;101(07):1145-1154 Doi: 10.1038/sj.bjc.6605289

59 Luo X, Sharff KA, Chen J, He TC, Luu HH. S100A6 expression and function in human osteosarcoma. Clin Orthop Relat Res 2008;466 (09):2060-2070 Doi: 10.1007/s11999-008-0361-x

60 Ohuchida K, Mizumoto K, Ishikawa N, et al. The role of S100A6 in pancreatic cancer development and its clinical implication as a diagnostic marker and therapeutic target. Clin Cancer Res 2005; 11(21):7785-7793 Doi: 10.1158/1078-0432.CCR-05-0714

61 Słomnicki LP, Leśniak W. S100A6 (calcyclin) deficiency induces senescence-like changes in cell cycle, morphology and functional characteristics of mouse NIH 3T3 fibroblasts. J Cell Biochem 2010; 109(03):576-584 Doi: 10.1002/jcb.22434

62 Okada H, Sanezumi M, Nakajima T, Okada S, Yasuda K, Kanzaki H. Rapid down-regulation of CD63 transcription by progesterone in human endometrial stromal cells. Mol Hum Reprod 1999;5(06): 554-558 Doi: 10.1093/molehr/5.6.554

63 Brar AK, Handwerger S, Kessler CA, Aronow BJ. Gene induction and categorical reprogramming during in vitro human endometrial fibroblast decidualization. Physiol Genomics 2001;7(02): 135-148 Doi: 10.1152/physiolgenomics.00061.2001

64 Tong XM, Lin XN, Song T, Liu L, Zhang SY. Calcium-binding protein $\mathrm{S} 100 \mathrm{P}$ is highly expressed during the implantation window in human endometrium. Fertil Steril 2010;94(04):1510-1518 Doi: 10.1016/j.fertnstert.2009.07.1667 